\title{
Global health research collaborations: lessons from the Fogarty International Center
}

Roger I Glass

From Institut Pasteur International Network Annual Scientific Meeting

Hong Kong. 22-23 November 2010

The Fogarty International Center at NIH has the mission of supporting training and research in global health with a focus on problems in low and middle income countries. Our programs provide research opportunities in both infectious and chronic diseases that link investigators and institutions in the United States with groups in the developing world. The value of these long term investments is evident by their ability to support cutting edge research while training local investigators to develop independent streams of funding and support. The presentation will provide examples of our activities that might have application within the network of the Institut Pasteur.

Submit your next manuscript to BioMed Central and take full advantage of:

- Convenient online submission

- Thorough peer review

- No space constraints or color figure charges

- Immediate publication on acceptance

- Inclusion in PubMed, CAS, Scopus and Google Scholar

- Research which is freely available for redistribution 